\title{
The profile of students' analytical skills in environmental issues of coastal area
}

\author{
Fenny Roshayanti a,1, ${ }^{*}$, Azizul Ghofar Candra Wicaksono a,2, Ipah Budi Minarti a,3 \\ a Department of Biology Education, Faculty of Mathematics, Science, and IT Education, Universitas PGRI Semarang, Jl. Sidodadi Timur No.24-Dr. \\ Cipto, Karangtempel, Semarang Timur, Semarang City, Central Java 50232, Indonesia \\ 1 fennyroshayanti@upgris.ac.id*, ${ }^{2}$ azizulwicaksono@upgris.ac.id, ${ }^{3}$ ipeh_mi2n@yahoo.co.id \\ * corresponding author
}

\begin{tabular}{|c|c|}
\hline ARTICLE INFO & ABSTRACT \\
\hline $\begin{array}{l}\text { Article history } \\
\text { Received January 29, } 2019 \\
\text { Revised February 16, } 2019 \\
\text { Accepted February 25, } 2019 \\
\text { Published March 05, } 2019 \\
\text { Keywords } \\
\text { Analytical skills } \\
\text { Coastal area } \\
\text { Environmental issues }\end{array}$ & $\begin{array}{l}\text { Environmental issues needed a lot of attention especially from high school students, } \\
\text { and their skill in solving environmental problem is important for the future. This research } \\
\text { was aimed to discover a profile of students' analytical skills toward environmental } \\
\text { issues. Three hundred twenty-nine high school students in coastal area are involved. } \\
\text { They had been given questionnaire about environmental issues. The result indicate that } \\
\text { the tested students has } 0.5690 \text { score as adequate level of analytical skills. Thus, } \\
\text { learning process need to be improved especially for environmental subject. }\end{array}$ \\
\hline
\end{tabular}

\section{INTRODUCTION}

The northern coastal area of Java, especially in Central Java with a coastal length about 415 kilometers mostly developed into industry, urban, port and tourism areas. The development of coastal areas into the center of economic activity will gradually suppress the ability of land, so it can disrupt the balancing capacity of the environment. Moreover, it found that there are many rubbish and pollution that even worsen the condition on coastal area (Marfai, 2011; Miladan, 2016; Setioko, 2010; Wanabakti, Susilo, Nathania, \& Putri, 2018). This problems result in decreasing of diversity, aberration and also erosion in coastline region with an average of 131.83 meters per year (Anna, 2010).

The area between the shoreline and the breaking wave became an area where the dynamic interaction between the water current and the sediment material are occurred. Moving water carried material from one place to another and results in eroding the sediment and then settles it somewhere that will cause the dropping of shoreline (Flemming, Harff, Moura, Burgess, \& Bailey, 2017; Kuznetsova \& Saprykina, 2019; Vargas-T, Uribe-P, Ríos-R, \& Castellanos-A, 2016; Wahyudi, Harijanto, \& Suntoyo, 2009). The worst condition was happened when the heavy rain falls which caused flood everywhere. This condition can affect the disruption of community activities in terms of transportation, industry, trade, environment and health. Aberration that occurred in Northern part of Central Java influenced people livelihood and giving damage to their field and 
houses (Damaywanti, 2013). Moreover it disrupts transportation that forced the local government to elevate and rebuild the main road (Arbib \& Seba, 2017; de Bruijn et al., 2019; Porter, 2016; Supriyanto, 2003).

In order to solve any issues in environment, it needs high quality human resource that having thinking ability and skills related to environment (Rafiei \& Davari, 2015). Thus, the environmental problem that happened in coastal area indirectly correlated with the low level of education there (Foresight: Migration and Global Environment Change, 2011; Nriagu, Udofia, Ekong, \& Ebuk, 2016; Remoundou \& Koundouri, 2009; Sherbinin, Carr, Cassels, \& Jiang, 2009). The education level of the majority of household heads did not complete primary school and a few of them graduated from junior high school (Manumoto, 2008; Priyono \& Febriany, 2013; Sommeiller \& Wodon, 2014; Suryadarma, Suryahadi, \& Sumarto, 2006). The children itself prefer to get a job after graduate from high schools. Furthermore, The education quality in coastal are low, the school could not provide best learning process, they had limited skills in technology and other facilities too (Amoako-Sakyi \& Amonoo-Kuofi, 2015; Masri, 2017; Rena, 2011).

This condition implies that the school in the north coastal area was not able to give positive influence in society. Basically, the practice of learning that had been done in north coastal schools should be like other schools, but there were some aspects that need to be improved both in terms of facilities and learning practice. Schools in the northern coastal areas have many obstacles to face compared to the other schools in big cities. They face environmental problems such as aberration and the rising of sea levels; people also have a low awareness of the importance of education and environmental sustainability. Most of local people work as fishermen and their children tend to follow them for work than going school. In addition, most parents have no awareness of giving motivation to their children for going to school and get high education (Birch, Savage, \& Ventura, 2007; Gershoff \& Font, 2016; Senterfitt, Shih, \& Teutsch, 2013; Winata \& Yuliana, 2010).

Because of that situation, the environmental education is needed in coastal area in order to solve many environmental issues that occur around them (Blumstein \& Saylan, 2007; Da-Silva-Rosa, Mendonça, Monteiro, De Souza, \& Lucena, 2015; Sawitri, 2016). High school need to improve and implement a best strategy to accommodate student's skill in solving environmental problem (Keselman, Levin, Kramer, Matzkin, \& Dutcher, 2011). Education is one aspect that can affect the world of the future and is the most effective way in shaping a society. The students as a part of school community also have a great contribution in the changing of society perspective in environmental issue (Idris, Gill, Ya'acob, Awal, \& Hassan, 2012). Students who develop their thinking skills have a chance to approach everyday problems including environmental issues using those competences (Birgili, 2015).

This study is aimed to map the students' analytical skills related to environmental issues in coastal area of Central Java. The student's skill in analyzing environmental issue is important as a good initiator to make change in solving coastal issues. It can be good information for school and educational stakeholder to develop the best approach to enhance students and school's participation in solving environmental issues.

\section{METHOD}

This research was categorized as survey with descriptive approach and quantitative analysis. The content of research was focused on students' analytical skills toward environmental issue especially in northern coastal area of Central java. This research was done in three months with involved 329 students of $10^{\text {th }}$-grade of Senior High School. The students came from seven districts in the northern coastal area of Central Java, including Brebes, Pekalongan, Pemalang, Batang, Semarang, Pati, and Jepara.

All of students who acted as respondents were given MSELS (Middle School Environmental Literacy Survey) questionnaire (B. McBeth, Hungerford, Marcinkowski, Volk, \& Meyers, 2008) which are categorized in four domains (ecological knowledge, cognitive skills, attitude, and behavior/action). Not all of domain in MSELS were involved. This study used cognitive skills-issues analysis domain as the main object of research with 14 items of analytical questions. This domain measured student's ability in analyzing environmental issues related to social value, environmental value, ethnocentrism value, economic value, and juridical value.

Some modification was made in the structure of MSELS to adjust the real condition in northern coastal area of Central Java, thus the questionnaire became more representative based on the real issues. The modification in MSELS were done in issue topic from "Controversy in the Wild West" become animal hunting that occur in coastal area and the using of coastal land for recreation area. The modification also was made in the character and the storyline. But the overall changes did not affect the core of issues analysis context in MSELS.

During the research process, the instrument was validated and tested with reliability test. The researchers then collected data by coming to school, giving MSELS questionnaires to students, getting monitored and checked the result of questionnaire done by students. The data gathered then analyzed using descriptive statistic and categorized by five levels as shown in Table 1. 
Table 1. Interval score of student's analytical issue

\begin{tabular}{cc}
\hline Score interval $(\%)$ & Criteria/level \\
\hline $81-100$ & excellent \\
$61-80$ & good \\
$41-60$ & adequate \\
$21-40$ & less developed \\
$\leq 21$ & worst \\
\hline
\end{tabular}

(Source: B. McBeth et al., 2008)

\section{RESULTS AND DISCUSSION}

Issues analysis is the one's ability to identify values associated with stances on issues such as environmental, legal, economic, ethnocentrism, and social issues. B. McBeth et al. (2008) stated that environmental value related to human activities with natural resources such as animal and plants and another organism. Legal value related to environmental issue with law suit, national, and state. Social value related to human empathy, feeling and status. Ethnocentric value is all about pertaining to a focus on the fulfilment of ethnic/cultural goals. While economic value related environment to money, material, and service.

The score of students' issues analysis is describe in Table 2. This finding showed that the student in coastal area of Java has middle level as total score in analysis issues as 0.569 in average. This result is not really different with American issue analytical skill of for both sixth- and eighth-grade levels students as $46 \%$ and $48 \%$ in score (McBeth, and Volk, 2009) as well as in Israelian students (Negev, Sagy, Garb, Salzberg, \& Tal, 2008).

Furthermore, high school student in Samboja, at the Kutai Kartanegara district-East Kalimantan has adequate score in cognitive skill of environmental literacy as 51\% (Nasution, 2016). In high school in Indonesia, environmental education was not learned independently as lesson subject. It usually merged with Biology subject and appeared in $10^{\text {th }}$-grade in second semester. Environmental issue showed as sub theme of ecology and pollution topic. Because of that, not all the teacher in coastal area can provide the whole and comprehensive lesson materials related to the environmental issues that occur in coastal area. Another problem came to the time allocation for learning environmental issues. Limited time allocation in lesson influence the teachers plan to bring the students to face real environment problem. This result indicated that student's skill in environmental issue analysis need to be improved. Thus, the environmental education is needed to reconstruct whether in curriculum, learning process or school management. It is important to prepare future student in facing global issues especially in environmental case.

Table 2. Issue analysis score in coastal high school students

\begin{tabular}{lccccc}
\hline & $\mathrm{N}$ & Minimum & Maximum & Mean & Std. Deviation \\
\hline Issues analysis & 329 & .00 & 1.00 & .5690 & .26205 \\
Male students & 115 & .00 & 1.00 & .5704 & .26694 \\
Female students & 214 & .00 & 1.00 & .5682 & .25579 \\
\hline
\end{tabular}

Moreover, when comparing to male and female students, there is no differences between their skills in issues analysis. The male student of coastal area has 0.5704 in analysis issues score in average. While female students have 0.5682 score in average. The different between male and female students is only 0.0022 in score or $0.22 \%$ that's mean there's no differences between both male and female students in analytical issue skills.

When it talks about gender, many research showed that gender will affect the analytical skill in any issues including environment (Ernst \& Monroe, 2004; O'Connor \& Joffe, 2014; Rakib, Islam, Nikolaos, Bodrud-Doza, \& Bhuiyan, 2017; Rippon, Jordan-Young, Kaiser, \& Fine, 2014). It also found that t-test analyses revealed that the older female students exhibited more support for environmental issues than did male students (Yilmaz, Boone, \& Andersen, 2004). In many aspect related to learning (thinking ability, motivation, literacy) people mostly found that female will give best result than male students (Below, 2010; Fatimah, 2017). But in this case, we found that both male and female students give same result when analyze environmental issue.

A lot of research support that no gender differences in critical thinking skills including analytical skill. Many similarities in gender of student's characteristics (Miri, David, \& Uri, 2007). Furthermore, it also founded that gender did not have an effect on students' metacognitive skill who related to student's skill in analytical task (Siswati, 2014). In addition, female students are characterize as giving more focus on concrete, practical and emotional things while male students have benefit in intellectual, abstract and objective matters. But that not 
clearly affect their learning result (Weaver-Hightower, 2003). However, coastal students give the same effort and thought in facing environmental issues. They also had same educational process related to environmental topic. Thus, both male and female students had the same potential and will give the similar response to environmental issues in the future.

The adequate level of students' analytical skill indicated that they have some difficulty. The difficulty to identify that issues and relate it to certain value occur in most of students. The result of students' issue analytical about environment is described in Table 3.

The result showed that students mostly had correct answer in legal value as $80 \%$. Followed by environmental value as $58 \%$, social and ethnocentric value as $51 \%$ both, and the last is economic value as $45 \%$ in score (Figure 1). The higher score of students was in legal value, that means students has great understanding about local government, public participation and law suit relating to environmental issues. The design of environmental policy is needed to understand environmental issues. The students also aware of government power to solve many environmental problems. The fact that government had huge impact to environment. Government regulation is important in providing a level playing field in any environmental issues (Rands et al, 2010). The environmental issues are one of public affair. It need public participation to raise control over decision making (O'Faircheallaigh, 2010). Yet, as democratic country, mass public in Indonesia has strong power nowadays. The right policy, good government and support from public will make environmental issues more easily to handle.

Table 3. Descriptive analysis about students' issue analysis

\begin{tabular}{lccccc}
\hline & $\mathrm{N}$ & Minimum & Maximum & Mean & Std. Deviation \\
\hline Social value & 329 & .00 & 1.00 & .5076 & .50070 \\
Environmental value & 329 & .00 & 1.00 & .5836 & .49371 \\
Ethnocentrism value & 329 & .00 & 1.00 & .5076 & .50070 \\
Economic value & 329 & .00 & 1.00 & .4498 & .49824 \\
Juridical value & 329 & .00 & 1.00 & .7964 & .40332 \\
\hline
\end{tabular}

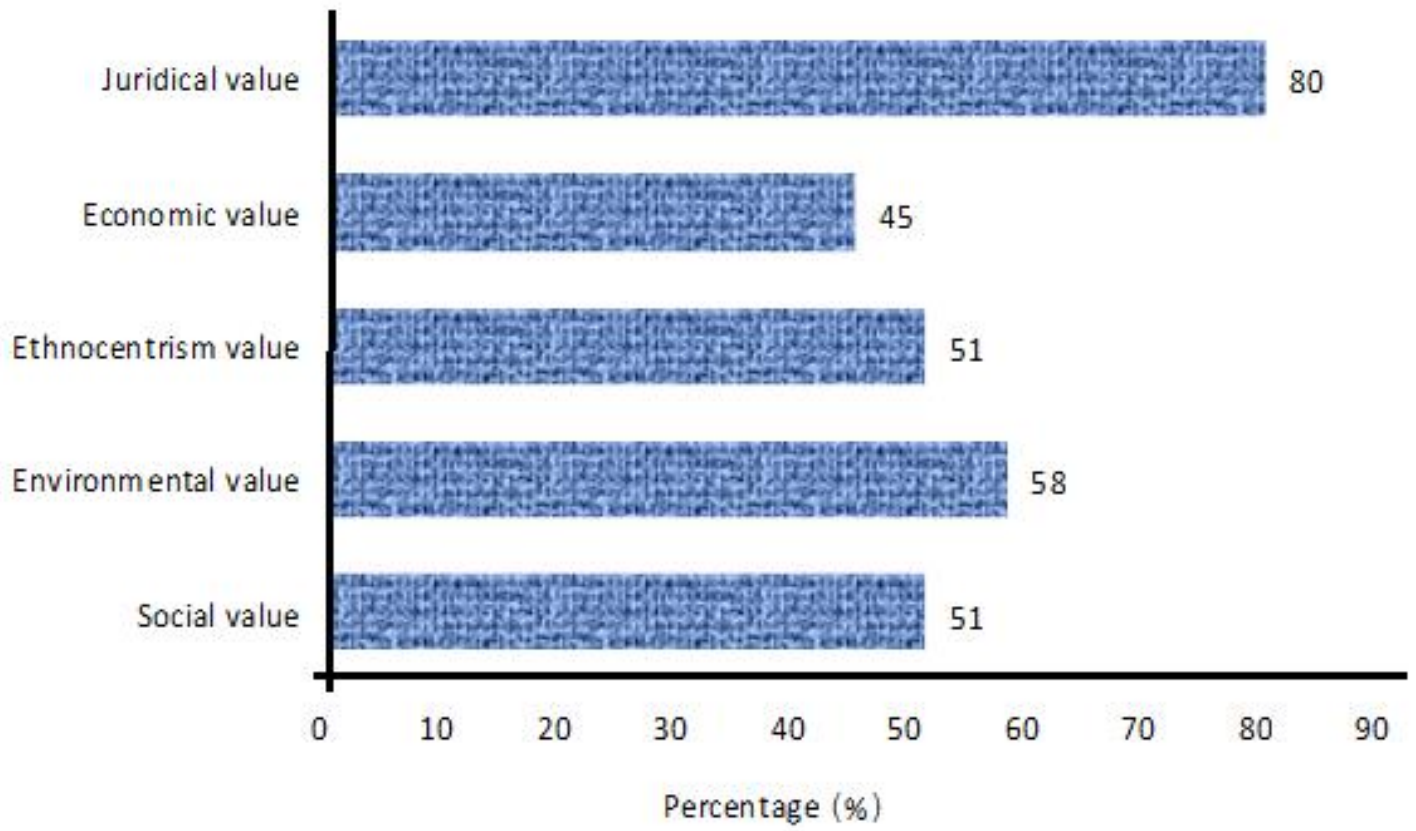

Figure 1. Percentage of each value related to environmental issues

The lowest score of student's issues analysis was in economic value. Student has difficulty to relate environmental issues with economic component such as market, money or service. Thus, there are strong relationship between economy and environment (Clapp \& Dauvergne, 2011; Gowdy, 2013; Tienhaara, 2014). They form mutual-influenced circulatory system. The global economy has relationship with environmental issues directly or indirectly especially when related to natural resources, agronomic, pollution (Halkos, 2013; 
Kolstad, 2011). So, the economic interference in environmental issues is great but it needed high ability to rethink about that complex relationship.

That condition can't afford by high school students yet. The students need to position themselves in any point of view, especially as economic agent. Yet, it needed a lot of experiences, but it can be achieved if school provide better learning process.

The value of environmental, ethnocentrism, and social has medium score around fifty percent. That means student has adequate understanding in relating environmental issues with organism life, human life and culture. That topic is learned frequently in educational process. Some topic such as the interaction between living things and their environment is well provided in curriculum. Unfortunately, it has no good score in student's analysis. Although there are many cultural integrations in education as an effect of decentralization in curriculum. This condition implied that learning process is needed to be improved because certain classroom practice related to students achievement (Wenglinsky, 2002). In Indonesia there are implementation gap between district and lack of appropriate teaching training also contribute to student's skill achievement (Yeom, Acedo, \& Utomo, 2002). So, it important to review how the environmental education goes through and made some improvement to it.

Based on the result of this research, holistic approach is needed to make students more aware and have good analytical thinking about environmental issue. It requires the work of all school components including teacher participation to integrate the real coastal environmental problems to their learning process and using best learning method to accommodate them. Furthermore, the schools itself should provide best culture to train students having attitude and behavior that pro-environment.

\section{CONCLUSION}

The student from coastal area of central java has medium score in analysis issues about environment as 0.5690 or $56.9 \%$. Between male and female students, there was no differences in analysis issues score. Mostly, student has best answer when related environmental issue with legal value with the highest score as $80 \%$. The lowest score was $45 \%$ when students analyze environmental issues related to economic value. Thus, this result implied that environmental education needs to develop with building pro environmental culture and integrate the topic of environmental issues into learning process and teacher should train their students how to develop higher thinking skills to prepare them for future environmental issues.

\section{REFERENCES}

Amoako-Sakyi, D., \& Amonoo-Kuofi, H. (2015). Problem-based learning in resource-poor settings: lessons from a medical school in Ghana. BMC Medical Education, 15(1), 1-8. doi: https://doi.org/10.1186/ s12909-015-0501-4

Anna, A. R., Suharjo, S., \& Kaeksi, R. . (2010). Rencana tataguna lahan wilayah pesisir berdasarkan proses abrasi di Pesisir Utara Jepara. In Seminar Nasional Penginderaan Jauh Dan Sistem Informasi Geografis (pp. 1-17). Universitas Muhammadiyah Surakarta. Retrieved from https://publikasiilmiah.ums. ac.id/handle/11617/1337?show=full

Arbib, J., \& Seba, T. (2017). A RethinkX sector disruption report: Rethinking transportation 2020-2030. Retrieved from https://static1.squarespace.com/static/585c3439be65942f022bbf9b/t/591a2e4be6f2e1c 13df930c5/1494888038959/RethinkX+Report_051517.pdf

Below, J. L., Skinner, C. H., Fearrington, J. Y., \& Sorrell, C. A. (2010). Gender differences in early literacy: Analysis of kindergarten through fifth-grade dynamic indicators of basic early literacy skills probes. School Psychology Review, 39(2), 240. Retrieved from https://eric.ed.gov/?id=EJ891851

Birch, L., Savage, J. S., \& Ventura, A. (2007). Influences on the development of children's eating behaviours: From infancy to adolescence. Canadian Journal of Dietetic Practice and Research, 68(1), s1-s56. Retrieved from https://www.ncbi.nlm.nih.gov/pmc/articles/PMC2678872/

Birgili, B. (2015). Creative and critical thinking skills in problem-based learning environments. Online Submission, 22(2), 71-78. doi:https://doi.org/10.18200/JGEDC.2015214253

Blumstein, D. T., \& Saylan, C. (2007). The failure of environmental education [And how we can fix it]. PLoS Biology, 5(5), 1. doi:https://doi.org/10.1371/journal.pbio.0050120

Clapp, J., \& Dauvergne, P. (2011). Paths to a green world: The political economy of the global environment. MIT press. Retrieved from http://www.jstor.org/stable/j.ctt5hhcr3

Da-Silva-Rosa, T., Mendonça, M. B., Monteiro, T. G., De Souza, R. M., \& Lucena, R. (2015). Environmental education as a strategy for reduction of socio-environmental risks. Ambiente \& Sociedade, 18(3), $211-$ 
230. doi: https://doi.org/10.1590/1809-4422ASOC1099V1832015

Damaywanti, K. (2013). Dampak abrasi pantai terhadap lingkungan sosial (Studi kasus di Desa Bedono, Sayung Demak). In Prosiding Seminar Nasional Pengelolaan Sumberdaya Alam dan Lingkungan 2013 (pp. 363-367). Pascasarjana Undip. Retrieved from http://eprints.undip.ac.id/40689/1/055-Kurnia_ Damaywanti.pdf

de Bruijn, K. M., Maran, C., Zygnerski, M., Jurado, J., Burzel, A., Jeuken, C., \& Obeysekera, J. (2019). Flood resilience of critical infrastructure: Approach and method applied to Fort Lauderdale, Florida. Water, 11(3), 517. doi: https://doi.org/10.3390/w11030517

Ernst, J., \& Monroe, M. (2004). The effects of environment-based education on students' critical thinking skills and disposition toward critical thinking. Environmental Education Research, 10(4), 507-522. doi: https:// doi.org/10.1080/13504620600942998

Fatimah, S. (2017). Analisis pemahaman konsep IPA berdasarkan motivasi belajar, keterampilan proses sains, kemampuan multirepresentasi, jenis kelamin, dan latar belakang sekolah mahasiswa calon guru SD. Jurnal Inovasi Pendidikan Dan Pembelajaran Sekolah Dasar, 1(1), 57-70. doi: https://doi.org/10. 24036/02017117934-0-00

Flemming, N. C., Harff, J., Moura, D., Burgess, A., \& Bailey, G. N. (Eds.). (2017). Submerged landscapes of the European continental shelf: Quaternary paleoenvironments. Hoboken, NJ: John Wiley \& Sons, Inc. Retrieved from https://books.google.co.id/books?isbn=1118927508

Foresight: Migration and Global Environment Change. (2011). Migration and global environmental change: Future challenges and opportunities. The Government Office for Science. London. Retrieved from https://www.gov.uk/government/uploads/system/uploads/attachment_data/file/287717/11-1116-migratio n-and-global-environmental-change.pdf

Gershoff, E. T., \& Font, S. A. (2016). Corporal punishment in U.S. public schools: Prevalence, disparities in use, and status in State and Federal Policy. Social Policy Report, 30(1), 1-26. doi: https://doi.org/10. 1002/j.2379-3988.2016.tb00086.x

Gowdy, J. (2013). Coevolutionary economics: The economy, society and the environment (1st ed.). Netherlands: Springer Netherlands. doi: https://doi.org/10.1007/978-94-015-8250-6

Halkos, G. . (2013). Exploring the economy-environment relationship in the case of sulphur emissions. Journal of Environmental Planning and Management, 56(2), 159-177. doi: https://doi.org/10.1080/096 40568.2012.657756

Idris, F., Gill, S. K., Ya'acob, A., Awal, N. A. M., \& Hassan, Z. (2012). The role of education in shaping youth's national identity. In Procedia-Social and Behavioral Sciences (Vol. 59, pp. 443-450). doi: https://doi.org/ 10.1016/j.sbspro.2012.09.299

Keselman, A., Levin, D. M., Kramer, J. F., Matzkin, K., \& Dutcher, G. (2011). Educating young people about environmental health for informed social action. Umw Gesundh Online, 4(December 2010), 1-8. Retrieved from https://www.ncbi.nlm.nih.gov/pubmed/24383062

Kolstad, C. (2011). Intermediate environmental economics (Inter. Ed.). London: Oxford University Press. Retrieved from https://books.google.co.id/books/about/Intermediate_Environmental_Economics.html?id =pzXKZwEACAAJ\&redir_esc=y

Kuznetsova, O., \& Saprykina, Y. (2019). Influence of underwater bar location on cross-shore sediment transport in the coastal zone. Journal of Marine Science and Engineering, 7(55), 1-12. doi: https://doi. org/10.3390/jmse7030055

Manumoto, D. (2008). Perubahan perilaku masyarakat kawasan pesisir akibat penurunan pendapatan sebagai dampak abrasi dan rob di Kabupaten Demak. In MP_Pros_C9_2009 (pp. 376-388). Departemen Pertanian. Retrieved from http://pse.litbang.pertanian.go.id/ind/pdffiles/MP_Pros_C9_20 09.pdf

Marfai, M. A. (2011). The hazards of coastal erosion in Central Java, Indonesia: An overview. Geografia Online, Malaysian Journal of Society and Space, 7(3), 1-9. Retrieved from http://journalarticle.ukm.my/ 2355/1/1.2011-3-MARFAI_ugm-english-1\%5B1\%5D_-_edited_28.8.pdf

Masri, A. (2017). The education for coastal fishermen children in Donggala. Asian Journal of Environment, History and Heritage, 1(1), 223-227. Retrievded from http://spaj.ukm.my/ajehh/index.php/ajehh/article/ view/21/42

McBeth, B., Hungerford, H., Marcinkowski, T., Volk, T., \& Meyers, R. (2008). National environmental literacy assessment project: Year 1 (No. NA06SEC4690009). Retrieved from https://www.noaa.gov/sites/default /files/atoms/files/Final_NELA_minus_MSELS_8-12-08_0.pdf 
McBeth, W., \& Volk, T. . (2009). The national environmental literacy project: A baseline study of middle grade students in the United States. The Journal of Environmental Education, 41(1), 55-67. doi: https:/l doi.org/10.1080/00958960903210031

Miladan, N. (2016). Communities' contributions to urban resilience process : a case study of Semarang city (Indonesia) toward coastal hydrological risk. Architecture, space management. Université Paris-Est. Retrieved from http://www.theses.fr/2016PESC1010.pdf

Miri, B., David, B. C., \& Uri, Z. (2007). Purposely teaching for the promotion of higher-order thinking skills: A case of critical thinking. Research in Science Education, 37(4), 353-369. doi: https://doi.org/10. 1007/s11165-006-9029-2

Nasution, Q. (2016). Analisis kemampuan literasi lingkungan siswa SMA Kelas X di Samboja dalam pembelajaran biologi. In Proceeding Biology Education Conference (pp. 352-358). Retrieved from https://jurnal.uns.ac.id/prosbi/article/view/5746

Negev, M., Sagy, G., Garb, Y., Salzberg, A., \& Tal, A. (2008). Evaluating the environmental literacy of Israeli elementary and high school students. The Journal of Environmental Education, 39(2), 3-20. doi: https:// doi.org/10.3200/JOEE.39.2.3-20

Nriagu, J., Udofia, E. A., Ekong, I., \& Ebuk, G. (2016). Health risks associated with oil pollution in the Niger Delta, Nigeria. International Journal of Environmental Research and Public Health, 13(3), 1-23. doi: https://doi.org/10.3390/ijerph13030346

O'Connor, C., \& Joffe, H. (2014). Gender on the brain: A case study of science communication in the new media environment. PLoS ONE, 9(10), 1-15. doi: https://doi.org/10.1371/journal.pone.0110830

O'Faircheallaigh, C. (2010). Public participation and environmental impact assessment: Purposes, implications, and lessons for public policy making. Environmental Impact Assessment Revie, 30(1), 19 27. doi: https://doi.org/10.1016/j.eiar.2009.05.001

Porter, G. (2016). Reflections on a century of road transport developments in West Africa and their (gendered) impacts on the rural poor. EchoGéo, 20, 0-16. doi: https://doi.org/10.4000/echogeo.13116

Priyono, E., \& Febriany, V. (2013). General senior secondary education financing in Indonesia. Jakarta: Education Sector Analytical and Capacity Development Partnership (ACDP) Agency for Research and Developments (Balitbang), Ministry of Education and Culture. Retrieved from http://www.smeru. or.id/sites/default/files/publication/acdp-004_general_senior_secondary_education_financing_in_indone sia.pdf

Rafiei, N., \& Davari, F. (2015). The role of human resources management on enhancing the teaching skills of faculty members. Materia Socio Medica, 27(1), 35. doi: https://doi.org/10.5455/msm.2014.27.35-38

Rakib, M. A., Islam, S., Nikolaos, I., Bodrud-Doza, M., \& Bhuiyan, M. A. H. (2017). Flood vulnerability, local perception and gender role judgment using multivariate analysis: A problem-based "participatory action to Future Skill Management" to cope with flood impacts. Weather and Climate Extremes, 18(October), 29-43. doi: https://doi.org/10.1016/j.wace.2017.10.002

Rands, M. R., Adams, W. M., Bennun, L., Butchart, S. H., Clements, A., Coomes, D., ... Sutherland, W. . (2010). Biodiversity conservation: Challenges beyond 2010. Science, 329(5997), 1298-1303. doi: https://doi.org/10.1126/science.1189138

Remoundou, K., \& Koundouri, P. (2009). Environmental effects on public health: An economic perspective. International Journal of Environmental Research and Public Health, 6(8), 2160-2178. doi: https://doi. org/10.3390/ijerph6082160

Rena, R. (2011). Challenges for quality primary education in Papua New Guinea-A case study. Education Research International, 2011, 1-11. doi: https://doi.org/10.1155/2011/485634

Rippon, G., Jordan-Young, R., Kaiser, A., \& Fine, C. (2014). Recommendations for sex/gender neuroimaging research: Key principles and implications for research design, analysis, and interpretation. Frontiers in Human Neuroscience, 8(August), 1-13. doi: https://doi.org/10.3389/fnhum.2014.00650

Sawitri, D. R. (2016). Early childhood environmental education in tropical and coastal areas: A meta-analysis. In IOP Conf. Series: Earth and Environmental Science (Vol. 55, p. 012050). IOP Publishing. doi: https:/l doi.org/10.1088/1755-1315/55/1/012050

Senterfitt, J. W., Shih, M., \& Teutsch, S. M. (2013). How social and economic factors affect health. Social Determinants of Health (Vol. 1). Los Angeles. doi: https://doi.org/10.1016/j.soilbio.2007.11.018

Setioko, B. (2010). The methamorphosis of a coastal city (Case study Semarang metropolitan). Journal of Coastal Development, 13(3), 148-159. Retrieved from https://media.neliti.com/media/publications/959 10-EN-the-methamorphosis-of-a-coastal-city-cas.pdf 
Sherbinin, A. De, Carr, D., Cassels, S., \& Jiang, L. (2009). Population and enviornment. Annual Review of Enviornmental Resources, 32, 345-373. doi: https://doi.org/10.1146/annurev.energy.32.041306.10024 3.Population

Siswati, B. H. (2014). Hubungan antara keterampilan metakognitif dengan hasil belajar siswa berkemampuan akademik berbeda pada pembelajaran biologi yang menerapkan beberapa model pembelajaran. Universitas Negeri Malang. Retrieved from http://karya-ilmiah.um.ac.id/index.php/disertasi/article/view/ 31478

Sommeiller, E., \& Wodon, Q. (2014). Enrolment gains from the elimination of primary school user fees in Burundi: Background paper for fixing the broken promise of education for all (Background paper). Retrieved from http://allinschool.org/wp-content/uploads/2015/02/OOSC-2014-QW-Burundi-Primaryfinal.pdf

Supriyanto, A. (2003). Analisis abrasi pantai dan alternatif penanggulangannya di perairan pesisir perbatasan Kabupaten Kendal-Kota Semarang. Diponegoro University. Retrieved from http://eprints.undip.ac.id/ 11334/1/2003MIL2232.pdf

Suryadarma, D., Suryahadi, A., \& Sumarto, S. (2006). Causes of low secondary school enrollment in Indonesia (SMERU Working Paper No. 371.219/DDC 21). Jakarta. Retrieved from https://media.neliti. com/media/publications/51095-EN-causes-of-low-secondary-school-enrollment-in-indonesia.pdf

Tienhaara, K. (2014). Varieties of green capitalism: Economy and environment in the wake of the global financial crisis. Environmental Politics, 32(2), 187-204. doi: https://doi.org/10.1080/09644016.2013. 821828

Vargas-T, V. H., Uribe-P, E., Ríos-R, C. A., \& Castellanos-A, O. M. (2016). Coastal landforms caused by deposition and erosion along the shoreline between Punta Brava and Punta Betín, Santa Marta, Colombian Caribbean. Revista de La Academia Colombiana de Ciencias Exactas, Físicas y Naturales, 40(157), 664-682. doi: https://doi.org/10.18257/raccefyn.387

Wahyudi, W., Harijanto, T., \& Suntoyo, S. (2009). Analisa kerentanan pantai di wilayah pesisir pantai Utara Jawa Timur. In SENTA 2009 (pp. 1-9). Surabaya: ITS Surabaya. Retrieved from http://personal.its.ac.id Ishow_publikasi.php?id=4254

Wanabakti, M. J., Susilo, C. R., Nathania, M., \& Putri, C. Y. (2018). Unraveling the impact of builtenvironmental self-modification of the local inhabitants in their attempt to reduce the urban flood impact in Grogol, Sukoharjo*. In IOP Conference Series: Earth and Environmental Science (Vol. 158, p. 012038). IOP Publishing. doi: https://doi.org/10.1088/1755-1315/158/1/012038

Weaver-Hightower, M. (2003). The "BoyTurn" in research on gender and education. Review of Educational Researc, 73(4), 471-498. doi: https://doi.org/10.3102/00346543073004471

Wenglinsky, H. (2002). How schools matter: The link between teacher classroom practices and student academic performance. Education Policy Analysis Archives, 10(2), 1-30. doi: https://doi.org/10.14507/ epaa.v10n12.2002

Winata, A., \& Yuliana, E. (2010). Peran masyarakat pesisir dalam penerapan strategi konservasi sumberdaya laut (Kasus di Kelurahan Pelabuhanratu, Kecamatan Pelabuhanratu, Kabupaten Sukabumi). Jurnal Matematika, Sains Dan Teknologi, 11(2), 122-132. Retrieved from http://jurnal.ut.ac.id/index.php/JMST /article/view/488

Yeom, M., Acedo, C., \& Utomo, E. (2002). The reform of secondary education in Indonesia during the 1990s: Basic education expansion and quality improvement through curriculum decentralization. Asia Pacific Education Review, 3(1), 56-68. doi: https://doi.org/10.1007/BF03024913.

Yilmaz, O., Boone, W. J., \& Andersen, H. O. (2004). Views of elementary and middle school Turkish students toward environmental issues. International Journal of Science Education, 26(12), 1527-1546. doi: https://doi.org/10.1080/0950069042000177280 